\title{
DAMPAK PRA DAN POST STRATEGI AKUISISI PADA KINERJA KEUANGAN PERUSAHAAN
}

\author{
Ahmad Yasir Ginanjar Mukti \\ Prodi Manajemen Universitas Mercu Buana Yogyakarta \\ Email: anjarmukti999@gmail.com \\ Asep Rokhyadi \\ Prodi Manajemen Universitas Mercu Buana Yogyakarta \\ Email: asep.rokhyadi@gmail.com
}

\begin{abstract}
Abstrack
This study aimed to compare the financial performance before and after the acquisition of PT Unilever Indonesia, Tbk acquired PT Sara Lee Body Care Indonesia in 2010.

Data analysis method used is multiple linear regression analysis. Hypothesis testing is done by using a statistical test paired sample t-test. The data used is data from Indonesian Capital Market Directory (ICMD) PT Unilever Indonesia, Tbk years 2006-2014. To detect normality test methods conducted by the Kolmogorov-Smirnov test.

Description of the variables used in this study is the liquidity ratio using the Current ratio (CR), the ratio leverage that uses Debt to Equity Ratio (DER), profitability ratios using the Net Profit Margin (NPM) and Return On Equity (ROE), Activities ratio using the Total Assets Turn Over (TATO).
\end{abstract}

Key word : Aquisition, Indonesian Capital Market Derictory, paired sample t test, kolmogorov-smirnov test.

\begin{abstract}
Abstrak
Penelitian ini bertujuan untuk mengetahui perbandingan kinerja keuangan sebelum dan sesudah akuisisi pada PT. Unilever Indonesia, Tbk yang mengakuisisi PT. Sara Lee Body Care Indonesia pada tahun 2010.

Metode analisis data yang digunakan adalah analisis regresi linear berganda. Pengujian hipotesis dilakukan dengan Uji statistik dengan menggunakan paired sample $t$ test. Data yang digunakan adalah data dari Indonesian Capital Market Derictory (ICMD) PT Unilever Indonesia, Tbk tahun 2006-2014. Untuk mendeteksi normalitas dilakukan dengan uji metode kolmogorov-smirnov test.

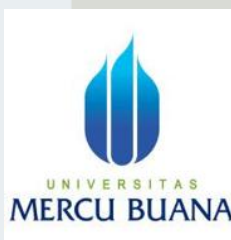

Jurnal Perilaku Dan Strategi bisnis

Vol. 4 No.1, 2016

Hal. $1-8$ Deskripsi variabel penelitian yang digunakan dalam penelitian ini adalah rasio likuiditas yang menggunakan Current ratio (CR), rasio laverage yang menggunakan Debt to Equity Ratio (DER), rasio profitabilitas yang menggunakan Net Profit Margin (NPM) dan Return On Equity (ROE), rasio aktivitas yang menggunakan Total Asstes Turn Over (TATO).
\end{abstract}

Kata kunci: Akuisisi, Indonesian Capital Market Derictory, paired sample t test, kolmogorovsmirnov test. 


\section{PENDAHULUAN}

Istilah merger, akuisisi dan pengambilalihan (konsolidasi), semuanya merupakan idiom merger dan akuisisi. Dalam merger, perusahaan-perusahaan menggabungkan dan membagi sumber daya yang mereka miliki untuk mencapai tujuan bersama. Akuisisi lebih merupakan sebuah perjanjian, sebuah perusahaan membeli aset atau saham perusahaan lain, dan para pemegang saham dari perusahaan yang menjadi sasaran akuisisi (perusahaan target) berhenti menjadi pemilik perusahaan.

Penggabungan usaha dilakukan atas dasar pertimbangan hukum, perpajakan atau alasan lainnya. Menurut Hartono (2003) akuisisi yang dilakukan oleh perusahaan didasari oleh beberapa alasan antara lain economic of scale, memperbaiki manajemen, penghematan pajak, diversifikasi, dan meningkatkan corporate growth rate. Economic of Scale atau tingkat skala ekonomi perusahaan dapat terjadi karena adanya sinergi atau perpaduan biaya overhead yang akan meningkatkan pendapatan yang lebih besar daripada jumlah pendapatan ketika tidak merger atau akuisisi. Sinergi tampak jelas ketika perusahaan yang melakukan merger berada dalam bisnis yang sama karena fungsi dan tenaga kerja yang berlebihan dapat dihilangkan.

Penggabungan usaha atau akuisisi ini juga dilakukan oleh PT. Unilever Indonesia ketika pada tahun 2010 mengakuisisi PT. Sara Lee Body Care Indonesia. PT. Unilever Indonesia mengakuisi 1.340.217 lembar saham PT. Sara Lee Body Care, atau setara dengan 89,348\%.

Akuisisi tentunya akan memberikan pengaruh pada perubahan kinerja perusahaan, diantaranya adalah kinerja keuangan perusahaan. Menilai kinerja keuangan, dapat dilakukan dengan beberapa cara, diantaranya dengan analisa rasio keuangan berdasar pada laporan keuangan perusahaan.

Analisis kinerja keuangan perusahaan digunakan sebagai suatu alat utama bagi manajemen dalam merencanakan kebijakan perusahaan. Rencana dapat disajikan dalam berbagai bentuk, akan tetapi rencana keuangan yang baik harus dikaitkan dengan kekuatan dan kelemahan pada saat ini. Kekuatan perusahaan harus dipahami jika hendak dimanfaatkan dengan tepat dan kelemahan perusahaan harus dikenali jika hendak dilakukan tindakan perbaikan (Weston and Copeland, 2001). Analisa keuangan dapat dilakukan dengan menganalisa rasio-rasio keuangan. Jenis rasio yang digunakan dalam penelitian ini terdiri dari rasio likuiditas, leverage, profitabilitas, dan aktivitas. Dasar logika dari pengukuran berdasar akuntansi adalah bahwa jika skala bertambah besar ditambah dengan sinergi yang dihasilkan dari gabungan aktivitas-aktivitas yang simultan, maka laba perusahaan akan meningkat dan kinerja perusahaan juga semakin meningkat sehingga kinerja perusahaan pasca merger dan akuisisi seharusnya semakin baik dibandingkan dengan sebelum merger dan akuisisi.

Beberapa penelitian telah dilakukan tentang analisa kinerja keuangan sebelum dan sesudah akuisisi, yaitu: (1) Novi Puji Lestari (2011), menghasilkan kesimpulan bahwa kinerja keuangan perusahaan pengakuisisi sebelum dan sesudah merger menunjukkan trend yang berbeda dan cenderung kearah penurunan kinerja. (2) Ahmed M. (2011) yang berkesimpulan bahwa Likuiditas, profitabilitas dan posisi modal tidak signifikan meningkat sedangkan efisiensi menurun setelah merger. (3) Edfan Darlis dan Zirman (2011) berkesimpulan bahwa terjadi peningkatan dan penurunan pada rasio-rasio keuangan (likuiditas, aktivitas, leverage, dan profitabilitas). Akan tetapi tidak cukup kuat untuk menunjukkan adanya pengaruh merger dan akuisisi terhadap rasio keuangan pada perusahaan pengakuisisi. (4) Nurul Hidayah (2013) menghasilkan kesimpulan bahwa berdasarkan dari perhitungan yang dilakukan pada rasio keuangan ROI, ROE, NPM, GPM, ATR, TATO, PER dan EPS sebelum dan sesudah akuisisi secara perhitungan menunjukkan adanya perubahan kenaikan dan penurunan yang terjadi karena beberapa alasan. (5) Putri Novaliza (2013) yang menghasilkan kesimpulan tidak ada perbedaan yang signifikan setelah 
perusahaan melakukan merger dan akuisisi. Sedangkan terhadap return saham, pengujian menunjukkan juga tidak ada perbedaan yang signifikan. (6) Iftia Putri (2013) Iftia Putri Utami (2013) tentang Pengaruh Profitabilitas Perusahaan Pengakuisisi menghasilkan kesimpulan bahwa tidak ada perbedaan profitabilitas pada perusahaan pengakuisisi.

Penelitian tersebut diatas sebagian besar menghasilkan kesimpulan bahwa kinerja keuangan perusahaan berdasar perhitungan rasio keuangan sebelum dan sesudah merger dan akuisisi menunjukkan penurunan dan peningkatan. Akan tetapi nilainya tidak cukup signifikan jika ingin dikatakan terdapat perbedaan. Sehingga dapat dikatakan tidak terdapat perbedaaan kinerja keuangan perusahaan sebelum dan sesudah merger dan akuisisi (Novi, 2011; Ahmed, 2011; Edfan, 2011; Putri, 2013; Iftia, 2013). Lain halnya dengan Nurul (2013) yang menyatakan bahwa terdapat peningkatan kinerja keuangan setelah melakukan merger dan akuisi. Penelitian tersebut diatas sebagian besar menghasilkan kesimpulan bahwa kinerja keuangan perusahaan berdasar perhitungan rasio keuangan sebelum dan sesudah merger dan akuisisi menunjukkan penurunan dan peningkatan. Akan tetapi nilainya tidak cukup signifikan jika ingin dikatakan terdapat perbedaan. Sehingga dapat dikatakan tidak terdapat perbedaaan kinerja keuangan perusahaan sebelum dan sesudah merger dan akuisisi (Novi, 2011; Ahmed, 2011; Edfan, 2011; Putri, 2013; Iftia, 2013). Lain halnya dengan Nurul (2013) yang menyatakan bahwa terdapat peningkatan kinerja keuangan setelah melakukan merger dan akuisi. Dengan demikian Temuan ini menarik untuk diteliti kembali yaitu mengenai pengaruh akuisisi terutama terhadap kinerja keuangan. Pengukuran kinerja keuangan dapat dilakukan dengan menggunakan analisis rasio, berdasarkan data dari laporan keuangan. Hasil dari analisis rasio tersebut akan dapat diketahui hasil-hasil finansial yang telah dicapai pada jangka waktu yang ditentukan serta dapat diketahui kelemahan-kelemahan yang dimiliki perusahaan dan kekuatan dari perusahaan.

Pengukuran kinerja keuangan memiliki beberapa tujuan (Munawir; 2002), yaitu pertama untuk mengetahui tingkat likuiditas atau kemampuan perusahaan untuk memenuhi kewajiban keuangan pada saat ditagih. Kedua untuk mengetahui tingkat leverage yaitu sejauh mana aktiva perusahaan dibiayai dengan hutang. Ketiga ntuk mengetahui tingkat profitabilitas, yaitu kemampuan perusahaan untuk mendapatkan laba selama periode tertentu. Keempat untuk mengatahui tingkat aktivitas yaitu seberapa efektif perusahaan dapat menggunakan semua sumber daya dalam pengendaliannya.

Atas dasar uraian tersebut maka penelitian ini didasarkan pada pertanyaan penelitian sebagai berikut:

1. Apakah terdapat perbedaan kinerja keuangan ditinjau dari Rasio Likuiditas (Current Ratio/CR), jika dibandingkan antara sebelum dan sesudah akuisisi pada PT. Unilever Indonesia, Tbk?

2. Apakah terdapat perbedaan kinerja keuangan ditinjau dari Rasio Leverage (Debt to Equity Ratio/DER), jika dibandingkan antara sebelum dan sesudah akuisisi pada PT. Unilever Indonesia, Tbk?

3. Apakah terdapat perbedaan kinerja keuangan ditinjau dari Rasio Profitabilitas (Net Profit Margin /NPM, Return on Equity/ROE) jika dibandingkan antara sebelum dan sesudah akuisisi pada PT. Unilever Indonesia, Tbk?

4. Apakah terdapat perbedaan kinerja keuangan ditinjau dari Rasio Aktivitas (Total Asset Turnover/TATO), jika dibandingkan antara sebelum dan sesudah akuisisi pada PT. Unilever Indonesia, Tbk?

\section{METODE PENELITIAN}

Penelitian ini merupakan penelitian deskriptif dengan pendekatan kuantitatf, karena berusaha memberikan gambaran tentang perbandingan kinerja keuangan perusahaan sebelum dan sesudah akusisi melalui perhitungan kuantitatif beberapa rasio keuangan. 
Sumber data yang digunakan dalam penelitian ini berupa data sekunder dari laporan keuangan perusahaan yang diterbitkan pada laporan keuangan terbuka. Data dalam penelitian ini diambil dari internet, yaitu melalui www.unilever.co.id/id/Investorcentre/annual-report.

Periode pengamatan tahun 2006-2014 pada perusahaan PT. Unilever Indonesia, Tbk dan PT. Sara Lee Body Care, Tbk. Yaitu 4 (empat) tahun sebelum akuisisi, dan 4 (empat) tahun setelah akuisisi. Data diperoleh menggunakan metode dokumentasi, yaitu dengan merangkum data atau catatan kertas kerja yang dianggap berhubungan dengan penelitian, berupa laporan keuangan yang terdiri dari neraca dan laporan laba rugi.

Variabel penelitian yang digunakan dalam penelitian ini adalah rasio-rasio keuangan yaitu rasio likuiditas (Current Ratio/CR), rasio Leverage (Debt Equity Ratio/ DER), rasio profitabilitas (Net Profit Ratio/NPM, Return on Equity/ROE), Rasio Aktivitas (Total Assets Turn Over/TATO).

\section{Teknik Analisa Data}

Teknik analisis menggunakan Paired Samples t Test untuk mengetahui dengan jelas perbedaan sebelum dan sesudah melakukan akusisi. Pengujian dilakukan dengan menggunakan metode Paired samples t Test untuk menguji sampel yang berpasangan.

Paired Samples t Test dilakukan setelah melakukan proses perhitungan CR, DER, NPM, ROE, dan TATO berdasarkan perhitungan dengan menggunakan rasio keuangan.

Normalitas data dilakukan dengan uji metode kolmogorov-smirnov test, pemilihan metode ini didasarkan bahwa kolmogorov- smirnov test merupakan metode yang umum digunakan untuk menguji normalitas data (Hair, 1998).

Pengujian ini menggunakan program SPSS versi 23.0 .

\section{HASIL PENELITIAN}

Data Indonesian Capital Market Derictory PT Unilever Indonesia, Tbk th 2006 - 2014 sebelum dan sesudah akuisisi maka dapat di deskriptifkan sebagai berikut:

Tabel 1.Deskripsi Data

\begin{tabular}{llllll}
\hline Variable & N & Minimum & Maximum & Mean & St. Daviation \\
\hline Current Ratio & 8 & 0,67 & 1,48 & 0,9950 & 0,29563 \\
Debt to Equity Ratio & 8 & 0,95 & 2,12 & 1,5187 & 0,54901 \\
Net Profit Margin & 8 & 0,15 & 0,18 & 0,1663 & 0,01188 \\
Return On Equity & 8 & 72,69 & 166,92 & 104,1525 & 33,71740 \\
Total Assets Turn Over & 8 & 2,24 & 2,45 & 2,3588 & 0,07882 \\
\hline
\end{tabular}


Tabel 2. Uji t sample paired t-test

\begin{tabular}{|c|c|c|c|c|c|c|c|c|c|}
\hline \multirow{3}{*}{$\frac{\frac{1}{2}}{\frac{\pi}{\infty}}$} & \multicolumn{8}{|c|}{ Paired differences } & \multirow{3}{*}{$\begin{array}{l}\text { Sig. } \\
(2- \\
\text { tailed) }\end{array}$} \\
\hline & & \multirow[t]{2}{*}{ Mean } & \multirow{2}{*}{$\begin{array}{c}\text { Std. } \\
\text { Daviation }\end{array}$} & \multirow{2}{*}{$\begin{array}{l}\text { Std. } \\
\text { Error } \\
\text { Mean }\end{array}$} & \multicolumn{2}{|c|}{$\begin{array}{l}\text { 95\% confidence } \\
\text { Interval of the } \\
\text { difference }\end{array}$} & \multirow[t]{2}{*}{$t$} & \multirow[t]{2}{*}{$d f$} & \\
\hline & & & & & lower & upper & & & \\
\hline & $\mathrm{X} 1 \mathrm{a}$ & & & & & & & & \\
\hline CR & $\&$ & 0,22000 & 0,45461 & 0,22730 & $-0,50338$ & 0,94338 & 0,968 & 3 & 0,405 \\
\hline & $\mathrm{X} 1 \mathrm{~b}$ & & & & & & & & \\
\hline & $\mathrm{X} 2 \mathrm{a}$ & & & & & & & & \\
\hline DER & $\begin{array}{c}\& \\
X 2 b\end{array}$ & 1,01250 & 0,08057 & 0,04029 & $-1,14071$ & $-0,88429$ & $-25,133$ & 3 & 0,000 \\
\hline & X3a & & & & & & & & \\
\hline NPM & $\begin{array}{c}\& \\
\times 3 b\end{array}$ & 0,01750 & 0,01258 & 0,00629 & $-0,03752$ & 0,00252 & $-2,782$ & 3 & 0,069 \\
\hline & $\times 4 a$ & & & & - & & & & \\
\hline ROE & $\begin{array}{c}\& \\
X 4 b\end{array}$ & 55,5950 & 19,79220 & 9,89610 & $\begin{array}{c}87,0888 \\
1\end{array}$ & 24,10119 & $-5,618$ & 3 & 0,011 \\
\hline & X5a & & & & & & & & \\
\hline TATO & $\&$ & 0,09750 & 0,08057 & 0,04029 & $-0,03071$ & 0,22571 & 2,420 & 3 & 0,094 \\
\hline & X5b & & & & & & & & \\
\hline
\end{tabular}

Berdasarkan Tabel 2, maka dapat diketahui sebagai berikut:

1. Current ratio (CR): berdasarkan hasil nilai Sig.(2-tailed) adalah sebesar 0,405 artinya lebih besar dari nilai signifikasi 0,05. Hal ini dapat disimpulkan bahwa nilai Current Ratio sebelum dan sesudah akuisisi tidak terdapat perbedaan yang signifikan.

2. Debt to Equity Ratio (DER): berdasarkan hasil nilai sig. (2-tailed) adalah sebesar 0,000 lebih kecil dari nilai signifikasi 0,05. Hal ini dapat di simpulkan bahwa Debt to Equity Ratio sebelum dan sesudah akuisisi terdapat perbedaan yang signifikan.

3. Net Profit Margin (NPM): berdasarkan hasil nilai Sig.(2-tailed) adalah sebesar 0,069 lebih besar dari nilai signifikasi 0,05. Hal ini dapat disimpulkan bahwa nilai Net Profit Margin sebelum dan sesudah akuisisi tidak terdapat perbedaan yang signifikan.

4. Return On Equity (ROE): berdasarkan hasil nilai Sig.(2-tailed) adalah sebesar 0,011 lebih kecil dari nilai signifikasi 0,05 . Hal ini dapat disimpulkan bahwa nilai Retrun On Equity sebelum dan sesudah akuisisi terdapat perbedaan yang signifikan.

5. Total Assets Turn Over (TATO): berdasarkan hasil nilai Sig.(2-tailed) adalah sebesar 0,094 lebih besar dari nilai signifikasi 0,05. Hal ini dapat disimpulkan bahwa nilai Total Assets Turn Over sebelum dan sesudah akuisisi tidak terdapat perbedaan yang signifikan.

\section{PEMBAHASAN}

Current Ratio (CR), sebelum dan sesudah akuisisi menunjukkan tidak ada perbedaan yang signifikan. Dengan demikian penelitian ini mendukung hasil penelitian dari Nurrul Hidayah (2012), dengan obyek penelitian yang sama, yaitu PT. Unilever Indonesia Tbk, setelah mengakuisisi PT Sara Lee Body Care Indonesia.

Penelitian ini juga mendukung penelitian oleh Putri Novaliza \& Atik Djajanti (2013) dan Muhammad Ahmed \& Zahid Ahmed (2011) bahwa setelah merger dan akuisisi, tidak ada perbedaan yang signifikan pada rasio keuangannya dan dikatakan tidak ada perbaikan yang signifikan, terutama pada current ratio yang terjadi.

Debt to Equity Ratio (DER) , menunjukkan bahwa ada perbedaan yang signifikan antara sebelum dan sesudah akuisi pada PT Unilever Indonesia Tbk setelah mengakuisisi PT Sara Lee Body Care Indonesia. Dengan demikian hasil penelitian ini berbeda dari hasil penelitian 
Muhammad Ahmed \& Zahid Ahmed (2011) dan Putri Novaliza \& Atik Djajanti (2013). Bahwa setelah merger dan akuisisi, tidak ada perbedaan yang signifikan pada rasio keuangannya dan dikatakan tidak ada perbaikan yang signifikan terutama pada Debt to Equity Ratio yang terjadi.

Net Profit Margin (NPM), sebelum dan sesudah akuisisi menunjukkan tidak ada perbedaan yang signifikan. Dengan demikian penelitian ini mendukung hasil penelitian dari Nurrul Hidayah (2012), dengan obyek penelitian yang sama, yaitu PT. Unilever Indonesia, setelah mengakuisisi PT Sara Lee Body Care Indonesia.

Penelitian ini juga mendukung penelitian oleh Putri Novaliza \& Atik Djajanti (2013), Iftia Putri Utami (2013), Muhammad Ahmed \& Zahid Ahmed (2011) dan Novi Puji Lestari (2011) bahwa setelah merger dan akuisisi, tidak ada perbedaan yang signifikan pada rasio keuangannya dan dikatakan tidak ada perbaikan yang signifikan dan menunjukkan trend yang berbeda dan cenderung kearah penurunan, terutama pada Net Profit Margin yang terjadi.

Return On Equity (ROE): sebelum dan sesudah akuisisi menunjukkan perbedaan yang signifikan. Dengan demikian hasil penelitian ini berbeda dari hasil penelitian dari Nurrul Hidayah (2012), dengan obyek penelitian yang sama, yaitu PT. Unilever Indonesia, setelah mengakuisisi PT Sara Lee Body Care Indonesia.

Penelitian ini juga berbeda dari hasil penelitian oleh Putri Novaliza \& Atik Djajanti (2013), Iftia Putri Utami (2013), Muhammad Ahmed \& Zahid Ahmed (2011) dan Novi Puji Lestari (2011) bahwa setelah merger dan akuisisi, tidak ada perbedaan yang signifikan pada rasio keuangannya dan dikatakan tidak ada perbaikan yang signifikan dan menunjukkan trend yang berbeda dan cenderung kearah penurunan, terutama pada Retrun On Equity yang terjadi.

Total Assets Turn Over (TATO), sebelum dan sesudah akuisisi menunjukkan tidak ada perbedaan yang signifikan. Dengan demikian penelitian ini mendukung hasil penelitian dari Nurrul Hidayah (2012), dengan obyek penelitian yang sama, yaitu PT. Unilever Indonesia, setelah mengakuisisi PT Sara Lee Body Care Indonesia.

Penelitian ini juga mendukung penelitian oleh Muhammad Ahmed \& Zahid Ahmed (2011), Putri Novaliza \& Atik Djajanti (2013) dan Novi Puji Lestari (2011) bahwa setelah merger dan akuisisi, tidak ada perbedaan yang signifikan pada rasio keuangannya dan dikatakan tidak ada perbaikan yang signifikan dan menunjukkan trend yang berbeda dan cenderung kearah penurunan, terutama pada Total Assets Turn Over yang terjadi.

Atik Djayanti (2013) dan Novi Puji Lestari (2011) nahwa setelah merger dan akuisisi, tidak ada perbedaan yang signifikan pada rasio keuangannya dan dikatakan tidak ada perbaikan yang signifikan pada Total Assets Turn Over. Diharapkan ini menjadi sistem informasi untuk pengambilan keputusan (Rokhyadi, 2012).

\section{KESIMPULAN}

Berdasarkan hasil analisis mengenai analisis perbandingan variabel rasio keuangan sebelum dan sesudah akuisisi didapatkan hasil sebagai berikut :

1. Tidak terdapat perbedaan nilai Current Ratio (CR) yang signifikan antara sebelum dan sesudah akuisisi.

2. Terdapat perbedaan nilai Debt to Equity Ratio (DER) yang signifikan antara sebelum dan sesudah akuisisi.

3. Tidak terdapat perbedaan nilai Net Profit Margin (NPM) yang signifikan antara sebelum dan sesudah akuisisi.

4. Terdapat perbedaan nilai Return on Equity (ROE) yang signifikan antara sebelum dan sesudah akuisisi.

5. Tidak terdapat perbedaan nilai Total Assets Turn Over (TATO) yang signifikan antara sebelum dan sesudah akuisisi. 


\section{SARAN}

Dalam penelitian ini terdapat kekurangan dan keterbatasan baik secara teknis maupun teoritis, antara lain:

1. Metode uji beda yang digunakan masih menggunakan uji parametrik (paired sampel ttest). Sehingga perlu disarankan untuk penelitian selanjutnya dapat menggunakan metode lainnya untuk uji yang lebih akurat.

2. Pengambilan data sample obyek penelitian menggunakan data tunggal dari PT Unilever Indonesia, Tbk. Sehingga perlu disarankan untuk menambah data sample obyek penelitian menggunakan perusahaan lain untuk variabelnya, dan variabel lain untuk perbandingan efektifitas.

3. Periode pengamatan penelitian 9 tahun, yaitu data per tahun 2006-2014. Sehingga perlu disarankan untuk memperpanjang waktu pengamatan atau membuat data tahunan menjadi quartal agar hasil penelitian lebih akurat.

\section{Daftar Pustaka}

Ahmed, Muhammad \& Ahmed, Zahid. (2011). Mergers and Acquisitions: Effect on Financial Performance of Manufacturing Companies of Pakistan. Middle-East Journal of Scientific Research 21 (4): 689-699, 2014, ISSN 1990-9233.

Brigham, Eugene \& Houston, Joe F. (2001). Manajemen Keuangan II. Jakarta: Salemba Empat.

Craven, W. David. (1998). Pemasaran Strategis. Jakarta: Erlangga.

Darlis, E. (2011). Dampak Publikasi Akuisisi Pada Perusahaan Pengakuisisi. Jurnal Ekonomi, 19(03).

Fahmi, Irham. (2012). Analisis Laporan Keuangan. Cetakan ke 2. Bandung: Alfabeta.

Gitosudarmo, Indriyo \& Basri. (2002). Manajemen Keuangan. Yogyakarta: BPFE.

Go, Marcell. (1992). Akuisisi Bisnis dan Pengelolaan. Jakarta: Rineka Cipta.

Hanadie, Mahmud M. (2005). Pengertian Analisis Rasio Keuangan, Diakses dari http://misriak.blogspot.com/ pada bulan mei 2015.

Harahap, Sofyan, (2006). Analisis Kritis Atas Laporan Keuangan. Edisi Pertama, Jakarta: Raja Grafindo Persada.

Harianto \& Sudomo, (2001). Perangkat dan Analisis Investasi di Pasar Modal Indonesia. Jakarta: PT. Bursa Efek Indonesia.

Hidayah, Nurul. (2013). Analisa Kinerja keuangan Sebelum dan Sesudah Akusisi (Studi Kasus terhadap PT. Unilever Tbk yang mengakusisi PT. Sara Lee Body Care Tbk) Periode tahun 2009-2011. Skripsi, Institut Manajemen Telkom, Bandung. Diakses melalui http://repository.telkomuniversity.ac.id. Pada bulan Maret 2015.

Hitt, Michael A. et al. (2001). Manajemen Strategis: Daya Saing dan Globalisasi; Konsep Buku 1. Jakarta: Salemba Empat.

Husnan, Suad. (1998). Manajemen Keuangan: Teori dan Penerapan Buku II, Edisi 4. Yogyakarta: BPFE.

Jumingan. (2006). Analisis Laporan Keuangan. Cetakan Pertama. Jakarta: PT. Bumi Aksara.

Lestari, Novi Puji. (2011). Manajemen Laba dan Kinerja Keuangan Perusahaan Pengakusisi Sebelum dan Sesudah Merger. Jurnal Manajemen Bisnis, Vol. 01 No. 02.

Moin, Abdul. (2003). Merjer, Akuisisi dan Divestasi. Yogyakarta: Ekonosia.

Mulyadi. (2007). Sistem Terpadu Pengelolaan Kinerja Personel Berbasis Balanced Scorecard. Yogyakarta: UPP STIM YKPN.

Munawir. (2004). Analisa Laporan keuangan. Edisi 2. Yogyakarta: Liberty.

Munawir. (2011). Analisa Laporan keuangan. Edisi 2. Yogyakarta: Liberty.

Novaliza, Putri. (2013). Analisa Pengaruh Merger dan Akusisi Terhadap Kinerja Perusahaan Publik di Indonesia (Periode 2004-2011). Jurnal Akuntasi dan Bisnis, Vol. 1 No. 1, September 2013. 
Payamta. (2004). Analisis Pengaruh Keputusan Merger dan Akuisisi Terhadap Perubahan Kinerja Perusahaan Publik di Indonesia. Jurnal Riset Akuntansi Indonesia, Universitas Sebelas Maret.

Riyanto, Bambang. (2004). Dasar-dasar Pembelanjaan Perusahaan. Edisi ke 4. Yogyakarta: BPFE.

Rokhyadi, A. (2012). Sistem informasi sebagai variabel moderasi pengaruh strategi inovasi terhadap kinerja perusahaan: hasil penelitian dosen muda. Program Studi Manajemen, Universitas Mercu Buana Yogyakarta.

Sucipto. (2003). Penilaian Kinerja Keuangan. FE Universitas Sumatera Utara.

Sudarsanam. (1999). The Essence of Merger and Acquisition, Edisi Pertama. Yogyakarta : Andi.

Sutrisno. (2009). Manajemen Keuangan Teori, Konsep dan Aplikasi. Yogyakarta: Ekonisia

Syamsuddin, Lukman. (2004). Manajemen Keuangan Perusahaan: Konsep Aplikasi dalam Perencanaan, Pengawasan, dan Pengambilan Keputusan. Jakarta: PT Raja Grafindo Persada.

Utami, Iftia Putri. (2013). Pengaruh Akuisisi Terhadap Profitabilitas Perusahaan Pengakuisisi (Studi Kasus Perusahaan Go Publik Pada Bursa Efek). Jurnal Manajemen 2.02.

Weston, J.Fred \& Copeland, T.E. (1996). Manajemen Keuangan. Edisi kedelapan. Jakarta: Binarupa Aksara

http://finance.detik.com/read/2010/06/27/174114/1387822/6, diakses pada tanggal 25 maret 2015).

http://sahamok.com/annual-report/laporan-tahunan-unilever-indonesia-tbk/, diakses pada tanggal 25 Maret 2015.

http://swa.co.id/tag/unilever-akuisisi-sara-lee, diakses pada bulan Maret 2015.

http://economy.okezone.com/.../akuisisi-unilever-ke-sara-lee-disetujui-kppu, diaksespada bulan Maret 2015

http://kppu.go.id/.../surat\%20tidak\%20keberatan\%20versi\%20publik.pdf, diakses pada bulan April 2015

http://finance.detik.com/.../pemegang-saham-sara-lee-setujui-akuisisi-unilever,diakses pada bulan April 2015. 